\title{
PEMANFAATAN KOMPUTER PENTIUM II SEBAGAI PC ROUTER DENGAN LINUX FREESCO DI SMK NEGERI 1 BAWANG
}

\author{
UTILIZATION OF COMPUTERS PENTIUM II AS PC ROUTER USING THE FREESCO LINUX \\ ROUTER AT SMK NEGERI I BAWANG
}

Adnan Purwanto, Alfin Hikmaturokhman, Aril Apria Susanto

${ }^{1,2,3}$ Program Studi Diploma III Teknik Telekomunikasi AKATEL Purwokerto

\begin{abstract}
ABSTRAKSI
Seiring semakin berkembangnya sistem operasi dan perangkat lunak komputer sekarang ini, maka berkembang pula perangkat keras komputer yang dibutuhkan untuk kebutuhan tersebut. Komputer-komputer lama yang tidak mendukung sistem operasi yang baru pun akhirnya terabaikan dan tidak digunakan. Namun komputer-komputer tersebut dapat dipergunakan kembali sebagai router. Linux Freesco adalah salah satu aplikasi router yang dapat digunakan sebagai alternatif pembuatan router yang berbasiskan komputer 386 dengan menggunakan resource yang kecil tetapi mempunyai kemampuan yang powerfull sebagai router. Linux Freesco merupakan sebuah proyek open source yang mengijinkan penggunanya untuk dapat mendistribusikan kembali dan memodifikasinya secara bebas tanpa harus membayar lisensi. Walaupun berbasis teks namun Linux Freesco dirancang untuk memudahkan penggunanya dimana semua perintah yang ada pada Linux Freesco dibuat secara interaktif. Penelitian ini mengimplementasikan Linux Freesco sebagai router di SMK Negeri 1 Bawang dan dikomparasikan dengan Linux Depdiknux yang sudah terpasang di SMK Negeri 1 Bawang. Dari hasil komparasi ternyata kemampuan Linux Freesco sebagai router sebanding dengan Linux Depdiknux yang sudah terpasang di SMK Negeri 1 Bawang, sehingga Linux Freesco dapat dijadikan router alternatif di SMK Negeri 1 Bawang dengan memanfaatkan komputer-komputer Pentium II yang tidak terpakai di SMK Negeri 1 Bawang.

Kata kunci : freesco, router, depdiknux
\end{abstract}

\begin{abstract}
Operating system and software computer are growing, so the hardware to support it. The computer is not support it can be used a router. Freesco Linux is one of the router application that can be used as an alternative to making a router-based computer 386 using the small resource but has powerful ability as a router. Freesco Linux is an open source project that allow users to redistribute and modified freely without having to pay a license. Freesco Linux is designed to facilitate users where all the commands in the Freesco Linux are made interactively. This final assignment of implementate Freesco Linux as a router in SMK Negeri 1 Bawang compared with Depdiknux Linux which is installed on the SMK Negeri 1 Bawang. From the comparation result show that Freesco Linux ability as the router as well as Depdiknux Linux that has been installed at SMK Negeri 1 Bawang, so Freesco Linux can be a alternative router at SMK Negeri 1 Bawang with using Pentium II computers.
\end{abstract}

Keywords: freesco, router, depdiknux

\section{PENDAHULUAN}

$$
\begin{aligned}
& \text { Router adalah perangkat keras yang } \\
& \text { dapat menghubungkan dua atau lebih } \\
& \text { jaringan yang memiliki subnet berbeda. }
\end{aligned}
$$

Router menggunakan satu atau lebih sistem metrik untuk menentukan jalur-jalur yang paling optimal dalam mengarahkan lalulintas antar jaringan yang memiliki subnet berbeda dengan berbasiskan pada Network 
Layer Information. Di SMK Negeri 1 Bawang terdapat komputer-komputer Pentium II yang sudah tidak mendukung sistem operasi terbaru namun dapat dimanfaatkan sebagi sebagai router dengan menggunakan Linux Freesco.

Tujuan penulisan penelitian ini adalah membangun $P C$ Router dengan memanfaatkan komputer-komputer Pentium II yang sudah tidak digunakan agar dapat dimanfaatkan sebagai router pada jaringan komputer sekolah sehingga dapat mengurangi biaya untuk pembelian perangkat keras router.

Linux Freesco adalah sebuah distribusi linux yang dapat dijalankan pada sebuah disket. Nama Freesco sendiri merupakan kepanjangan dari 'FREE cisCO', dan dapat diartikan dengan Cisco gratis. Namun Freesco ini sama sekali tidak ada hubungannya dengan sistem operasi SCO Unix atau CISCO. Linux Freesco adalah distribusi linux yang freeware dengan naungan lisensi GNU General Public License (GPL) sehingga setiap orang bebas untuk mendistribusikan dan menggunakannya.

Spesifikasi minimum yang dibutuhkan untuk dapat menjalankan Linux Freesco adalah:

- Sebuah CPU 386 atau lebih baik lagi.

- RAM minimal $8 \mathrm{Mb}$ dengan swap disarankan $16 \mathrm{Mb}$ atau lebih baik

- Floppy Disk Drive $1.44 \mathrm{Mb}$

- Hardisk - (opsional) tapi jika menginginkan penambahan fitur lainnya dapat menggunakan harddisk berukuran ratusan megabyte sampai 2 gigabyte.

- Ethernet

- Modem-(opsional)

Fitur yang disertakan dalam Linux Freesco versi 3.8 adalah sebagai berikut :

- Kernel Linux 2.0.39 + IP masquerade

- DNS Server

- DHCP Server

- $\quad$ Time Server

- Remote HTTP

- Print Server

- FTP Server

- Dukungan PPPoE

- Ident Server

\section{METODE PENELITIAN}

\section{Metode Eksperimen}

Pada metode ini penulis bereksperimen dengan membuat sebuah PC Router dengan memanfaatkan komputer Pentium II di SMK Negeri 1 Bawang.

\section{Metode Pengumpulan Data}

Metode pengumpulan data yang digunakan adalah dengan mengumpulkan data primer, dimana data yang diambil dari hasil dari eksperimen yang telah dilakukan, dengan parameter berupa kecepatan koneksi.

\section{Metode Analisa}

Analisa dilakukan dengan membandingkan kinerja Freesco PC Router menggunakan komputer Pentium II dengan Linux Depdiknux yang menggunakan Komputer Pentium IV. 


\section{INSTALASI LINUX FREESCO}

\section{Kebutuhan perangkat}

a. Komputer dengan sistem operasi Windows XP Professional SP 3 yang memiliki floppy diskdrive.

b. Komputer yang akan digunakan sebagai $P C$ Router yang memiliki spesifikasi :

- Prosesor : Intel PENTIUM II

- $R A M: 32 \mathrm{~KB}$

- 2 buah Ethernet Card

- Hardisk $600 \mathrm{Mb}$

\section{Tahapan Instalasi}

Sebelum memulai tahap instalasi, download terlebih dahulu aplikasi Linux Freesco di http://freesco.sourceforge.net kemudian ekstrak pada folder sementara, misalnya adalah : buat folder c:/Freesco. Untuk selanjutnya dilakukan instalasi pada floppy disk.

\section{a. Instalasi pada Floppy Disk}

- klik START > RUN, pada kotak dialog RUN ketik 'command' untuk masuk pada mode DOS Prompt pada Windows 95 atau 98 atau ketikkan 'cmd' pada Windows XP.

- Setelah masuk pada DOS Prompt, masuk ke direktori dimana letak file Freesco berada dengan mengetikkan C: $1>$ CD Freesco

- Kemudian ketikkan make_fd.bat a:

- File Linux Freesco akan terpasang pada floppy disk yang terpasang pada drive
- Instalasi pada floppy disk selesai.

\section{b. Instalasi pada Hardisk}

Sebelum menginstalasi Freesco Linux pada Hardisk, pastikan bahwa hardisk yang akan digunakan telah diformat dengan file sistem FAT 16 atau FAT 32 dan telah berisi sistem sehingga dapat booting, dengan cara :

- Masuk pada DOS Prompt, kemudian ketikkan perintah format e:/s yang berarti melakukan format hardisk pada drive e: dengan menambahkan sistem.

- Setelah hardisk terformat, restart komputer dan kemudian booting dari floppy disk.

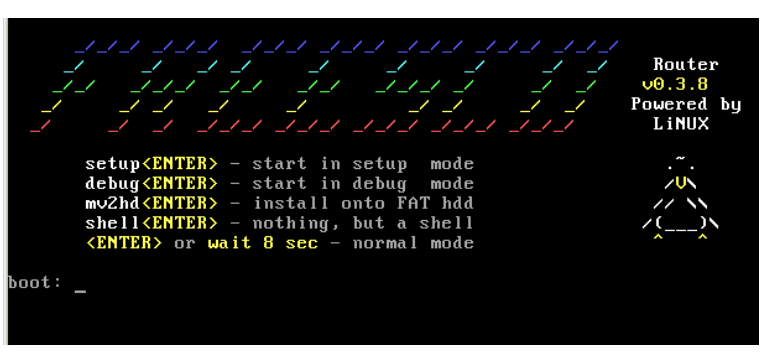

Gambar 1 : Tampilan awal Linux Freesco

- untuk Memasangkan Linux Freesco pada hardisk, selanjutnya kita pilih pilihan yang ketiga, yaitu mv2hd [enter]

- Kemudian pada layar akan muncul perintah seperti terlihat pada gambar III.2.

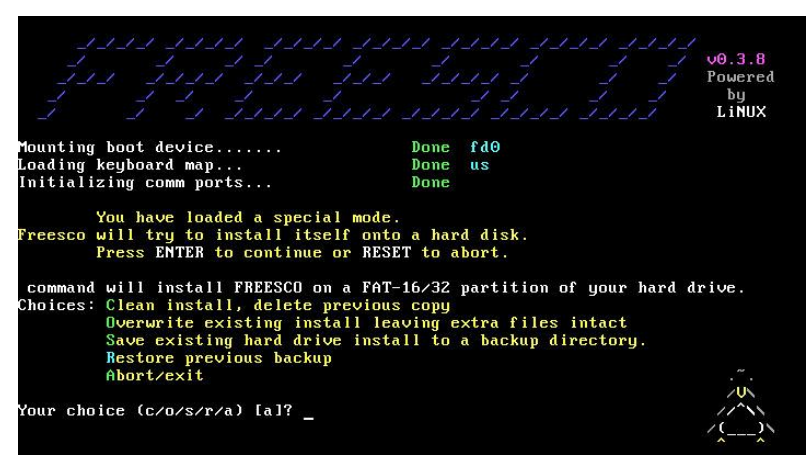

Gambar 2 : Opsi instalasi Linux Freesco pada hardisk

- A: 
- Terdapat 5 pilihan yang akan dilakukan pada instalasi yaitu:

(c) clean install, delete previous copy : akan menginstalasi pada hardisk, dengan menghapus semua file Linux Freesco pada hardisk tersebut (jika ada). Pilihan ini dilakukan apabila akan melakukan instalasi Linux Freesco yang baru.

(o) overwrite existing install leaving extra file intact : pilihan ini akan menimpa instalasi yang sudah ada pada hardisk tersebut dan akan membiarkan file ekstra Linux Freesco untuk dapa dipergunakan kembali pada instalasi baru.

(s) save existing hardisk install to backup directory: membuat backup pada instalasi yang sudah terdapat pada hardisk pada direktori backup.

(r) restore previous backup, :

mengembalikan backup yang tersimpan pada directory backup untuk dipergunakan kembali.

(a) abort/exit : membatalkan instalasi pada hardisk.

- Karena kita memilih instalasi baru maka kita pilih (c) clean install

- Selanjutnya proses instalasi berlangsung. Setelah semua terinstall pada hardisk maka muncul perintah untuk melakukan reboot.

- Instalasi selesai. Lakukan reboot dengan menekan Ctrl + Alt + Del

\section{KONFIGURASI LINUX FREESCO}

\section{Gambaran Jaringan SMK Negeri 1 Bawang}

Sebelum dilakukan konfigurasi Linux Freesco, gambar 3 adalah gambaran jaringan komputer yang ada di SMK Negeri 1

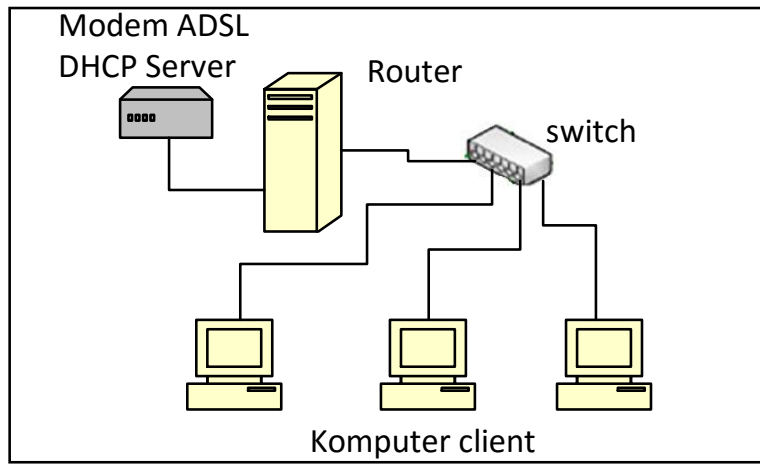

Gambar 3 : Struktur Jaringan SMK Negeri 1 Bawang

Konfigurasi Internet Address yang digunakan adalah :

Modem ADSL Router :

- IP Address ： 192.168.1.1

- Subnetmask : 255.255.255.0

- DNS : 202.134.1.10

- Setting sebagai DHCP Server

Router :

- Ethernet 0 : IP Address $\quad$ : DHCP Client

- Ethernet 1 :

$$
\text { IP Address : 192.168.2.1 }
$$

- Subnet mask : 255.255.255.0

Komputer Client

- IP Address :

192.168.2.2 - 192.168.2.254

- Subnetmask : 255.255.255.0

- Gateway : 192.168.2.1

- DNS :202.134.1.10

\section{Langkah-langkah Konfigurasi Linux} Freesco 
Setelah instalasi Linux Freesco Selesai Selanjutnya kita akan mulai melakukan konfigurasi dari Linux Freesco sesuai dengan fungsi yang akan kita gunakan. Secara keseluruhan konfigurasi dilakukan secara interaktif yang disajikan menu Linux Freesco secara langkah demi langkah. Beberapa informasi yang cukup penting kita ketahui adalah beberapa keterangan mengenai kode warna yang digunakan dalam konfigurasi Linux Freesco sebagai berikut :

Hijau, untuk parameter yang harus dikonfigurasi

Kuning, parameter optional

Merah, parameter yang diperuntukan bagi yang benar-benar paham untuk mengkonfigurasinya

Setelah melakukan booting, maka muncul tampilan DOS Prompt C/:> . Pada DOS Prompt, ketikkan router.bat atau cukup ketikkan router, maka akan muncul tampilan Linux Freesco seperti gambar 4:

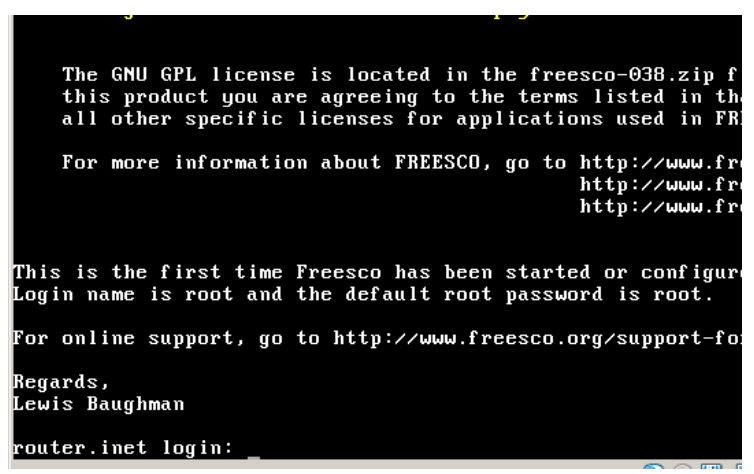

Gambar 4 : Tampilan login Linux Freesco

- Pertama kali kita akan diminta untuk masuk dengan username "root" dan password "root" yang merupakan username dan password default.
- Masukkan username "root" dan password "root"!

- Maka muncul di layar muncul tampilan baru seperti gambar 5

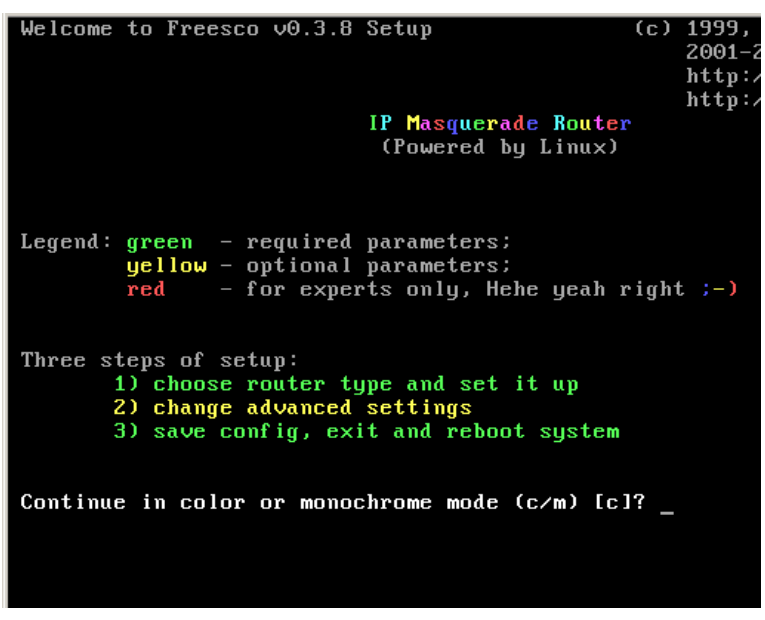

Gambar 5 Memilih tampilan warna Linux Freesco

Terdapat panduan yaitu 3 langkah pemasangan dan konfigurasi Linux Freesco

- Choose router type and set it up, yaitu : pilih tipe router atau server yang akan digunakan.

- Change advance settings, yaitu : ubah konfigurasi

- Save config, exit and reboot system, yaitu : simpan konfigurasi, keluar dan kemudian reboot system

- Pertanyaan yang ada adalah : continue in color or monochrome mode (c/m) [c]? pilih c [enter] untuk masuk dalam mode tampilan warna.

- Setelah muncul dialog menu baru yaitu CHOOSE ROUTER/SERVER TYPE yang merupakan menu interaktif yang memandu untuk konfigurasi Linux Freesco, seperti terlihat pada gambar 6 . 


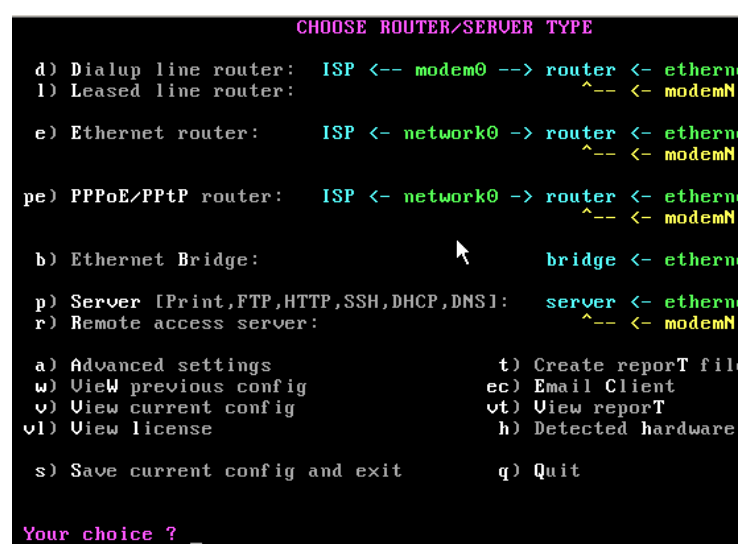

Gambar 6 : Pilihan tipe server / router Linux Freesco

Dari menu CHOOSE ROUTER/SERVER TYPE, kita pilih a) Advanced setting dengan mengetikkan "a". Muncul tampilan Advance Setting Menu yang menampilkan seluruh menu perintah yang ada pada Linux Freesco.

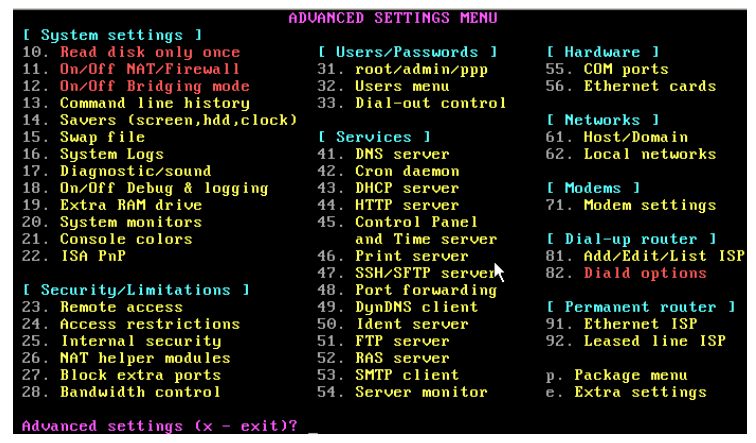

Gambar 7 : Menu Spesifik Linux Freesco

Untuk melakukan setting IP Address pada NIC yang ada pada komputer kita pilih 62 [enter]. Selanjutnya akan menampilkan tampilan seperti gambar 8

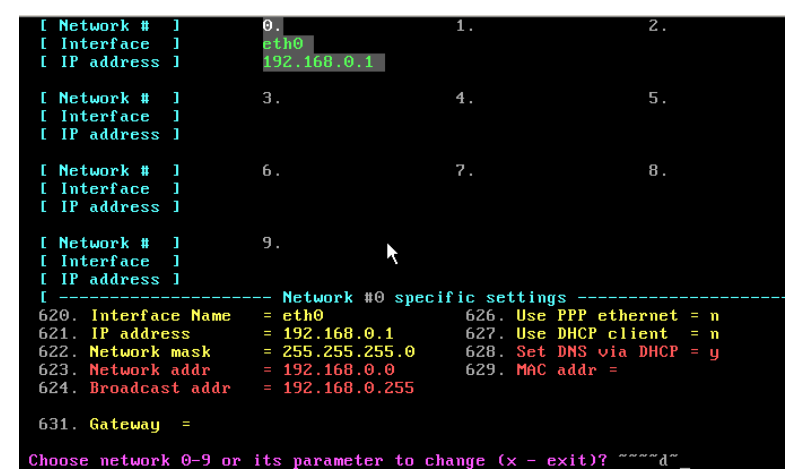

Gambar 8 : Pengaturan IP Address pada Linux

Freesco

Untuk memilih Ethernet Card yang akan kita konfigurasikan kita bisa mengetikkan angka 0 - 9 diikuti dengan [enter]

\section{a. Konfigurasi Ethernet 0}

- Ketik: 0 [enter] untuk konfigurasi ethernet 0

- Ketik: 627 [enter] untuk mengkonfigurasi router ini sebagai DHCP client, karena modem/router di level atasnya menggunakan DHCP server dalam pengaturan IP Addressnya maka kita tidak repot mengatur IP yang akan kita pasangkan pada ethernet 0 . Kita tinggal pilih user DHCP Client dengan mengetikkan angka 627. Secara otomatis IP Address [621] Network mask [622] terbentuk dengan sendirinya, tanpa kita harus mengkonfigurasi. Begitu juga dengan dengan DNS dan pengaturan lainnya. secara otomatis akan terisi.

\section{b. Konfigurasi Ethernet 1}

- Ketik 1 [enter] untuk mengkonfigurasi ethernet 1

- Ketik 620 [enter] untuk memasukkan Interface Name. Ketik : eth1[enter] 
- Ketik 621[enter] untuk memasukkan IP Address, dilanjutkan dengan nomor $I P$ Adresss yang dimaksud, yaitu

\subsubsection{1[enter]}

- Ketik 622 [enter] untuk memasukkan network mask, yaitu 255.255.255.0 [enter].

Sehingga tampilan akhir untuk ethernet 1 akan terlihat seperti gambar berikut ini:

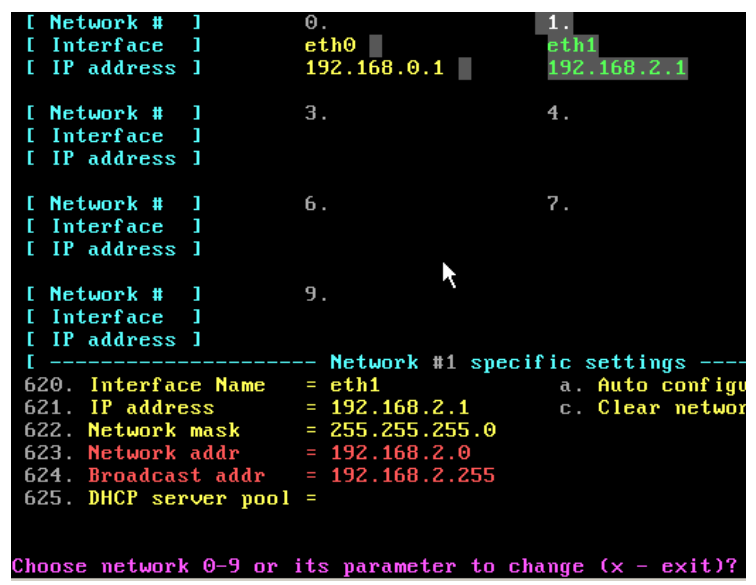

Gambar 9 : Konfigurasi Eth1 Linux Freesco

Setelah EthO dan Ethl sudah dikonfigurasi kita keluar dari Advance Menu dengan menekan $\mathbf{x}$ [enter], kemudian $\mathbf{x}$ [enter] hingga kembali masuk ke menu utama. Untuk menyimpan setting ini ke dalam hardisk, maka kita tekan s [enter]. Secara otomatis router akan restart dan konfigurasi yang kita buat sudah dapat dipergunakan.

\section{KONFIGURASI PADA CLIENT (WINDOWS XP)}

Pada komputer client kita hanya tinggal mengaktifkan konfigurasi jaringan saja. Adapun untuk mengatur IP Address kita masuk ke Control Panel > Network. Kemudian klik kanan Properties.

Setelah muncul kotak dialog, pilihlah TCP/IP Properties dengan dengan memberikan IP Address seperti pada gambar 10 :

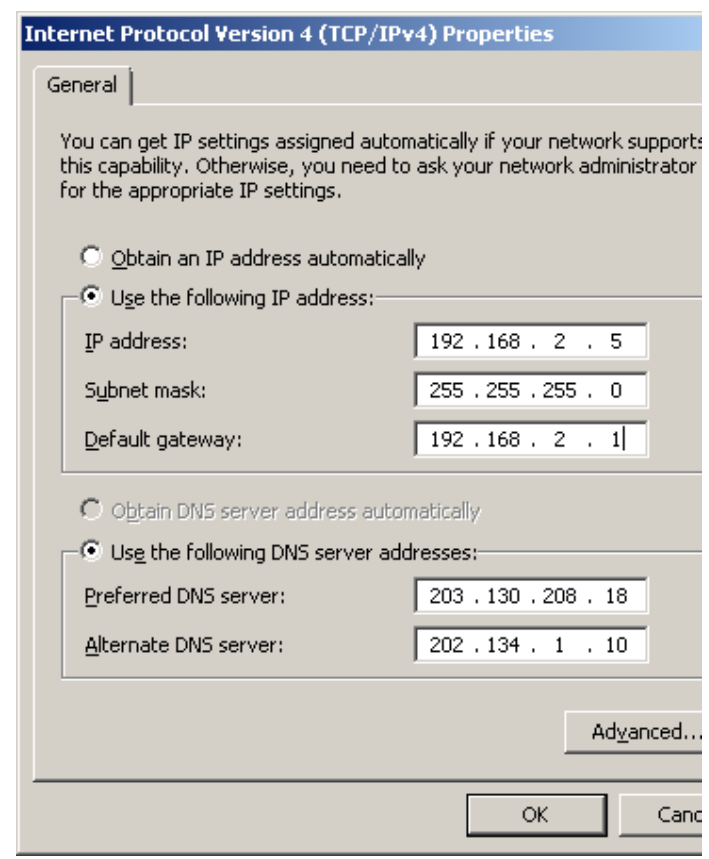

Gambar 10 : Pengaturan IP Address pada komputer

client

\section{KOMPARASI DAN ANALISA HASIL}

Untuk dapat melakukan analisa hasil akhir dari instalasi Linux Freesco ini maka dilakukan komparasi atau perbandingan antara Linux Freesco dengan Linux Depdiknux yang sudah terpasang di jaringan SMK Negeri 1 Bawang. 


\section{A. Metode Pengujian}

1. Download dari client pada jaringan internet

Pengujian yang dilakukan adalah dengan cara melakukan download secara bergantian dengan menggunakan satu komputer client melalui router Linux Freesco dan Linux Depdiknux.

Untuk melakukan perhitungan 2. Pengujian bandwith dari Speedtest.net

Pengujian yang dilakukan adalah dengan cara melakukan uji koneksi menggunakan komputer client secara bergantian melalui router Linux Freesco dan Linux Depdiknux. Jeda waktu yang digunakan untuk setiap kali pengetesan adalah 2 jam.

waktu download digunakan aplikasi

Free Download Manager.

\section{B. Hasil Pengujian}

1. Download melalui client menggunakan jaringan internet

Tabel 1 : Hasil Komparasi download Linux Freesco dan Linux Depdiknux

\begin{tabular}{|r|l|r|r|r|}
\hline \multirow{2}{*}{ No. Nama File } & \multicolumn{1}{|c|}{$\begin{array}{c}\text { Ukuran } \\
\text { (dalam kb) }\end{array}$} & \multicolumn{2}{|c|}{ Waktu Download (dalam detik) } \\
\cline { 4 - 5 } & & 7.090 & 129 & \multicolumn{1}{c|}{ Freesco } \\
\hline 1. & Firefox Setup 3.0.10.exe & 14.800 & 423 & 513 \\
\hline 2. & Moodle1.9.5.zip & 8.400 & 111 & 60 \\
\hline 3. & Terminator Salvation Trailer HQ.flv & 261 & 8 & 7 \\
\hline 4. & Giva-report.doc & 185.000 & 1.965 & 2.096 \\
\hline 5. & Sabily-packages.iso & 53 & 25 & 7 \\
\hline 6. & Lecture-10-penulisan-tugas-atau-skripsi.pdf & 341 & 26 & 55 \\
\hline 7. & Modul TA.ppt & 470 & 12 & 96 \\
\hline 8. & Gimp-course.pdf & 3.272 & 133 & 205 \\
\hline 9. & Wink20.zip & 1.790 & 20 & 25 \\
\hline 10 & Install_flash_player.exe & 696.000 & 9.051 & 9.542 \\
\hline 11. & Pclinuxos-2009.1.iso & 2.297 & 32 & 31 \\
\hline 12. & Ungu dilema cinta.flv & 109 & 21 & 32 \\
\hline 13. & IPScan.exe & 28.700 & 354 & 475 \\
\hline 14. & avira_antivir_personal_en.exe & 4.307 & 681 & 493 \\
\hline 15. & The_changcuter_mainserong.mp3 & 952.890 & $\mathbf{1 2 . 9 9 1}$ & 14.152 \\
\hline
\end{tabular}


2. Pengujian Bandwith pada http://www.speedtest.net

Tabel 2 : Hasil Komparasi bandwith pada http://www.speedtest.net

\begin{tabular}{|c|c|c|c|c|}
\hline \multirow{2}{*}{ No } & \multicolumn{2}{|c|}{$\begin{array}{c}\text { Freesco (dalam } \\
\text { Mbps) }\end{array}$} & \multicolumn{2}{c|}{$\begin{array}{c}\text { Depdiknux (dalam } \\
\text { Mbps) }\end{array}$} \\
\cline { 2 - 5 } & Download & Upload & Download & Upload \\
\hline 1 & 0,69 & 0,10 & 0,70 & 0,10 \\
\hline 2 & 0,34 & 0,09 & 0,58 & 0,10 \\
\hline 3 & 0,67 & 0,08 & 0,58 & 0,10 \\
\hline 4 & 0,32 & 0,09 & 0,19 & 0,09 \\
\hline 5 & 0,69 & 0,09 & 0,79 & 0,09 \\
\hline 6 & 0,18 & 0,07 & 0,25 & 0,05 \\
\hline 7 & 0,18 & 0,06 & 0,23 & 0,08 \\
\hline 8 & 0,31 & 0,05 & 0,25 & 0,06 \\
\hline 9 & 0,24 & 0,09 & 0,31 & 0,06 \\
\hline 10 & 0,59 & $\mathbf{0 , 1 0}$ & 0,54 & 0,08 \\
\hline Jumlah & $\mathbf{4 , 2 1}$ & $\mathbf{0 , 8 2}$ & $\mathbf{4 , 4 2}$ & $\mathbf{0 , 8 1}$ \\
\hline Rata-rata & $\mathbf{0 , 4 2}$ & $\mathbf{0 , 0 8}$ & $\mathbf{0 . 4 4}$ & $\mathbf{0 , 0 8}$ \\
\hline & & & & \\
\hline
\end{tabular}




\section{Analisa Pengujian}

Dari hasil download file melalui internet dengan komputer client yang melalui router yang menggunakan Linux Freesco ternyata lebih baik dari pada menggunakan Linux Depdiknux. Hal ini terlihat dari tabel 1.

Dari hasil pengujian bandwith melalui http://www.speedtest.net diperoleh hasil bahwa rata-rata hasil pengujian download, Linux Depdiknux lebih baik daripada Linux Freesco tetapi pada pengujian upload hasil rata-rata yang diperoleh cukup berimbang. Hal ini terlihat pada hasil pengujian pada tabel 2 .

Dari hasil pengujian download dan uji koneksi melalui http://speedtest.net yang telah dilakukan dapat diperoleh hasil bahwa Linux Freesco mampu melakukan routing dengan baik sebagaimana router Depdiknux yang selama ini digunakan di SMK Negeri 1 Bawang. Sehingga Linux Freesco dapat direkomendasikan sebagai router alternatif yang dapat digunakan di SMK Negeri 1 Bawang.

\section{KESIMPULAN}

1. Linux Freesco merupakan sebuah sistem operasi yang bersifat open source (terbuka) sehingga siapa saja dapat menggunakan, memodifikasinya bahkan mengembangkannya tanpa harus membayar lisensi. Dengan begitu akan mengurangi biaya dalam hal pembelian perangkat lunak.

2. Dengan Linux Freesco bisa dijadikan alternatif pembuatan router berbasis $P C$ dengan pemanfaatan komputer- komputer yang sudah tidak mendukung sistem operasi terbaru yang memerlukan sumber daya yang lebih besar. Dengan komputer sekelas Pentium II, bisa membuat router jaringan yang handal. Tentunya hal ini akan mengurangi pengeluaran dalam pembelian perangkat keras router.

3. Instalasi Linux Freesco cukup mudah dan tidak memerlukan waktu yang lama.

4. Pengoperasian Linux Freesco cukup mudah karena menggunakan menumenu yang interaktif dan langkah demi langkah sehingga konfigurasinya tidak memakan waktu yang lama dan pengguna tidak terlalu dipusingkan dengan perintah-perintah linux yang rumit.

5. Kehandalan Linux Freesco sebagai router dengan menggunakan komputer Pentium II sebanding dengan menggunakan Linux Depdiknux yang menggunakan perangkat keras yang lebih baru daripada yang digunakan Linux Freesco.

6. SMK Negeri 1 Bawang dapat menggunakan Linux Freesco sebagai alternatif pengganti router dengan mempergunakan kembali komputerkomputer Pentium I dan Pentium II yang lama tidak dipergunakan dan hanya tersimpan di bengkel. Sehingga SMK Negeri 1 Bawang tidak perlu mengeluarkan biaya yang besar untuk pembelian perangkat keras router. 
Linux Freesco merupakan sebuah sistem operasi yang bersifat open source (terbuka) sehingga siapa saja dapat menggunakan, memodifikasinya bahkan mengembangkannya tanpa harus membayar lisensi. Dengan begitu akan mengurangi biaya dalam hal pembelian perangkat lunak.

Dengan fasilitas yang dimiliki Linux Freesco, maka bisa dijadikan alternatif pembuatan router berbasis $P C$ dengan pemanfaatan komputer-komputer yang sudah tidak mendukung sistem operasi terbaru yang memerlukan sumber daya yang lebih besar. Dengan komputer sekelas Pentium II kita bisa membuat router jaringan yang handal. Tentunya hal ini akan mengurangi pengeluaran dalam pembelian perangkat keras router.

Walaupun linux freesco berbasis text, namun pengoperasiannya cukup mudah karena menggunakan menu-menu yang interaktif dan langkah demi langkah sehingga instalasi dan konfigurasinya tidak memakan waktu yang lama dan pengguna tidak terlalu dipusingkan dengan perintah-perintah linux yang rumit.

Kehandalan Linux Freesco sebagai router dengan menggunakan komputer Pentium II ternyata sebanding dengan menggunakan Linux Depdiknux yang menggunakan perangkat keras yang lebih baru daripada yang digunakan Linux Freesco. Terbukti hasil komparasi yang telah dilakukan antara Linux Freesco dan Depdiknux hasilnya tidak jauh berbeda.

Dengan demikian di SMK Negeri 1 Bawang dapat menggunakan Linux Freesco sebagai alternatif pengganti router dengan mempergunakan kembali komputer-komputer Pentium I dan Pentium II yang lama tidak dipergunakan dan hanya tersimpan di bengkel. Sehingga SMK Negeri 1 Bawang tidak perlu mengeluarkan biaya yang besar untuk pembelian perangkat keras router.

\section{DAFTAR PUSTAKA}

Anonymous.2009. CPU: http://id.wikipedia.org/wiki/cpu. Wikipedia (diakses 8 Juni 2009)

2009. Komputer:

http://id.wikipedia.org/wiki/komputer. Wikipedia (diakses 8 Juni 2009)

.2009.Network Address

Translation:

http://id.wikipedia.org/wiki/Network_a ddress_translation. Wikipedia (diakses 17 Februari 2009)

.2009. Pentium:

http://id.wikipedia.org/wiki/Pentium.

Wikipedia (diakses 8 Juni 2009)

2009. Pentium II:

http://id.wikipedia.org/wiki/pentium_ii . Wikipedia (diakses 8 Juni 2009)

Daulay, Melvin Syafrizal.2007. Modul

Teori Jaringan Komputer:

Modul_jaringan_komputer.doc.

Dingetje. 2003. Freesco Dokuwiki:

http://dingetje.homeip.net/dokuwiki 
/freesco/manuals/ (diakses 22 April 2009)

Fredrik, 2008. Freesco Tutorial:

http://bakskuru.se/fredrik/freesco/af ib/index.html (diakses 11

November 2008)

Jokersteve.2009. Pengetahuan Tentang

Router:

http://www.jasakom.com/forum/vie

wtopic.php? $\mathrm{f}=162 \& \mathrm{t}=5733 \& \mathrm{sid}=3 \mathrm{c}$

fb89eff5944a20c46c6c1caaf42c82.

Forum Jasakom. (diakses 8 Juni 2008)

Mustafa, Khalid. 2006. Depdiknux Linux

untuk Jardiknas dan ICT Center:

depdiknux_install_pdf.pdf
Nugraha, Dindin. 2003. FREESCO (Free CISco): Linux Untuk PC Router: www.ilmukomputer.com. IlmuKomputer.

Storozhebykh, Serge V. 2002. Freesco Manual 0.30 (English): en-030man.zip.Freesco.Org.

Sudirman, Ivan. 2003. Sejarah Komputer: ivansudirman-sejarahkomputer.pdf. IlmuKomputer.com

Susanto, Irwan. 2004. Panduan Penulisan Tugas Akhir : Purwokerto.

Akademi Teknik Telekomunikasi Sandhy Putra.

Wagito. 2005. Jaringan Komputer Teori dan Implementasi Berbasis Linux: Yogyakarta. Gava Media 